\title{
Dr Alexander Gordon of Aberdeen
}

\section{Lesley Smith}

\section{Navy surgeon}

One of the shining lights in the history of obstetrics was Dr Alexander Gordon, who was born in Strachan, about 20 miles south west of Aberdeen in 1752. He studied at Marischal College, where he obtained an MA, and graduated in medicine from Aberdeen University.

In 1780, Gordon entered the Navy as surgeon's mate and 2 years later achieved the rank of surgeon. The intensely challenging, cramped and often poorly lit conditions of a ship's surgeon's table would have forced Gordon to perform his skills under the most difficult of conditions. Literally buckets of blood, sawn crushed limbs and the moral dilemma of whom to save when choices had to be made.

Most practitioners at this time settled into the fashionable ease of a private practice, excellent financial rewards with the right client list and a social whirl in the upper-middle classes. Gordon was different. He was interested in medicine for its own sake and passionate about trying to save his patients, constantly seeking the company of the best in their field and studying whenever possible. Two doctors had a particular impact on Gordon, namely Thomas Denman and William Osborn, both of whose lectures he regularly attended in 1783 at the Middlesex Lying-in Dispensary in Shore Street, London. It is also known that he practised dissection and surgery at the Westminster Hospital.

\section{Aberdeen physician}

At 33 years of age, Gordon, now a highly experienced surgeon, returned to his native Aberdeen, gained an MD, and shortly afterwards was appointed physician to the Aberdeen Dispensary at the same time as running a popular private practice. The Aberdeen Dispensary had only been open for 4 years when Gordon was appointed in 1785 . Gordon would have been at the forefront of his profession and some of his ideas brought from the latest medical conferences may well have caused a stir. He was known to have a particular interest in obstetrics.

\section{Puerperal fever}

In 1789 and 1792 the Aberdeen region suffered serious epidemics of puerperal fever. The rapid and apparently unstoppable contagion must have made Gordon despair as he fought to save the lives of women. We know he personally treated 77 such patients of whom 25 died, usually on, or near the fifth day.

It was these frustrating and distressing experiences that drove Gordon to consider the nature of the disease and how it progressed. He started to appreciate that the presentation of the symptoms and the timing, not only of the length of

J Fam Plann Reprod Health Care 2010; 36(4): 253

Tutbury Castle, Tutbury, UK

Lesley Smith, Curator

Correspondence to: Lesley Smith, Tutbury Castle, Tutbury, Staffordshire DE13 9JF, UK. E-mail: info@tutburycastle.com the illness prior to death, but also of who had attended that woman, were crucial. Gordon became aware of the infectious nature of contagious puerperal fever and contagion, and observed that there was a direct link between the attendance of a doctor, midwife or nurse and contagion. Gordon became convinced of this and published his findings under the title "A Treatise on Epidemic Puerperal Fever in Aberdeen" in 1795, which was reprinted in the American Journal of Obstetrics and Gynaecology in 1928. The treatise contains the poignant sentence: "It is a disagreeable declaration for me to mention that I myself was the means of carrying the infection to a great number of women".

Centuries later it is extraordinary to read how Gordon is able, in another important section of the treatise, to draw an analogy between puerperal fever and erysipelas as the lymphatic glands absorb near the wound.

Gordon's many hours in the practice of dissection enabled him to demonstrate the pathology of the condition that had a principal link with the peritoneum and also the ovaries. Gordon further demonstrated that he understood, with clarity, the very nature of infectious puerperal fever.

All this was achieved without the science or understanding of bacteria but with great observational skills and the ability to understand that there may be patterns in illness. Gordon advised those treating such patients to wash themselves thoroughly and ensure their clothing was properly fumigated before going to the bedside of another patient.

\section{Final years}

When Gordon was 43 years old he was again summoned by the Admiralty for active service on the ships. Shortly afterwards he contracted tuberculosis and was sent home to his wife Elizabeth and daughter. He died in 1779 at the age of 47 years. His was a short life by our standards but one that reminds us of the fathers of obstetrics and of science as we know it today.

\section{Acknowledgement}

The author would like to thank Dr G Williams, British Museum, London, UK for his help and advice.

\section{Further reading}

1 Abrams R. Touching Distance. London, UK: Macmillan, 2008.

2 Dunn PM. Dr Alexander Gordon (1752-99) and contagious puerperal fever. Arch Dis Child Fetal Neonatal Ed 1998; 78: F232-F233.

3 Aberdeen University holds a numbers of papers in its archives that make fascinating reading for those wishing to track the development of understanding contagious puerperal fever and the work of Dr Alexander Gordon.

About the author

Lesley Smith is currently a postgraduate student in the Centre for the History of Medicine of the University of Birmingham, where she is developing a PhD in obstetrics and gynaecology in early modern Britain. She holds an honorary degree for "services to history". She makes 200-300 public appearances a year and also works as a TV historian in the UK and abroad including the USA. Lesley is also Curator of Tutbury Castle in Staffordshire and is a member of the Society of Apothecaries of London and the Society of Medical Writers.

\section{Visit the Faculty Website at www.fsrh.org}

